\title{
The Direct and Indirect Effect of Enterprise Resource Planning System Implementation on Firm Performance through the Organizational Capabilities as a Mediator
}

\author{
Euphrasia Susy Suhendra1, Mitha Filandari, Emmy Indrayani, Maulana
}

\begin{abstract}
In the midst of rapidly changing business environment and technological advancement, ERP becomes the solution for companies to improve efficiency and effectiveness by integrating existing system thus that companies can increase their performance. Using $R B V$ approach, companies can properly manage their resources through the organizational capabilities also play an important role in improving firm performance. This paper aims to examine the effect of ERP system implementation on firm performance both directly and indirectly through the organizational capabilities as intervening variable at manufacturing companies listed on Indonesia Stock Exchange period 2013-2017 which consists of 100 samples of ERP Adopters and Non-Adopters. The conceptual model in this study tested and analyzed using PLS-based SEM. The results showed that the implementation of ERP system has significant effect on firm performance and organizational capabilities. Organizational capabilities also have significant effect on firm performance. In addition, organizational capabilities have proven to mediate the relationship between ERP system and firm performance. This shows that the implementation of ERP system makes the information system to be integrated thus it enable companies to be more efficient and will affect the organizational capabilities in maximizing the utilization of company resources that ultimately can improve the firm performance.
\end{abstract}

\section{INTRODUCTION}

In today's highly dynamic business environment, the biggest challenge for companies is to remain viable and competitive. The main part of this dynamics business environment is the rapid increase of technology and information technology (1). In times of increasing global competition, information technology (IT) and information systems (IS) play an important role in the business environment (2). Using information technology to improve activities produces a set of resources that competitors cannot easily imitate thus that effective use of information technology expected to improve efficiency by streamlining business processes and the use of information system has the potential to improve the performance of the company when

Revised Manuscript Received on April 19, 2019.

Euphrasia Susy Suhendra, professor of Management in Gunadarma University, Indonesia.

Mitha Filandari, Economics Graduate Majoring, Accounting and Master Graduate In Management Information System, Gunadarma University, Indonesia.

Emmy Indrayani, Lecturer and Researcher in Gunadarma University Jakarta, Indonesia.

Maulana, Lecturer and Researcher in Tamansiswa Palembang University, Indonesia.
Keywords: ERP System, Firm Performance, RBV Approach

its ability channeled to develop a specialized corporate competence (3). The development of technology is currently use by many companies in assisting the smooth operation of activities at various divisions in the company by implementing the software system required by each division. The challenge faced by many companies is to incorporate or consolidate the heterogeneous systems on every division within the company. To face the challenges posed by the various transaction systems that exist within an entity, the action that can be taken is to adopt the Enterprise Resource Planning (ERP) system.

ERP system is an example of the most strategic tool for planning, coordinating and controlling processes within organizations (4). ERP provides a rich source of information that enables companies to support business strategies that generate growth, and innovation (5). ERP is a term derived from material resource planning and is an information system that integrates and automates all departments within a company, such as finance, human resources, manufacturing, logistics, etc. to help in manage the overall of the company's resources that have integrated functions in one system (4). However, the successful implementation of the ERP system cannot ensure that the company will get value from the system. In order that implementation of ERP systems can provide value, there are three keys of its ability that should be considered, such as using Resource-Based Value (RBV) approaches, ERP resources, organizational capabilities and core competencies of the organization (6). $\mathrm{RBV}$ is the main theory that has been adopted to interpret the relationship between IT and firm performance. The basic argument of RBV states that firm performance is determined by its resources (7). Companies who want to gain a higher competitive advantage need to build collaborative relationships with the ability to implement ERP systems, and once companies ensure what they do to implement them successfully, they can enhance firm performance. Therefore, research on the implementation of ERP systems on firm performance cannot be separated from the ability or the capability of the company (2).

However, with all the benefits offered, there is a big challenge for many organizations in implementing ERP and sometimes, it may just be a waste of money if it was installed before the company is really ready for it. 
Organizations must understand and identify factors in terms of individual, organizational, and technological characteristics when complex information systems such as ERP are implemented within an organization (8). Moreover, Asian companies face very different issues than the issues faced by companies in the developed world. This is due to differences in management style, business model, data format, level of sophistication of IT usage and so on (9). This makes ERP implementation more challenging in developing countries than developed countries, as most ERP systems are designed in developed countries (10). Therefore, it is important to know how the impact of the ERP systems implementation on firm performance in developing countries such as Indonesia, especially in the manufacturing sector that has an important role for the Indonesian economy as the leading sector which contributes the most to Indonesia's economic growth.

Table 1. The Growth of Manufacturing Industry GDP without Oil and Gas and the Contribution to National GDP at Constant Price (y-on-y)

\begin{tabular}{|c|c|c|c|c|c|c|}
\hline \multirow[t]{2}{*}{ Description } & $\begin{array}{l}201 \\
2\end{array}$ & $\begin{array}{l}201 \\
3\end{array}$ & $\begin{array}{l}201 \\
4\end{array}$ & $\begin{array}{l}201 \\
5\end{array}$ & $\begin{array}{l}201 \\
6\end{array}$ & $\begin{array}{l}201 \\
7\end{array}$ \\
\hline & \multicolumn{6}{|l|}{$(\%)$} \\
\hline National GDP & 6.03 & 5.56 & 5.02 & 4.79 & 5.08 & 5.05 \\
\hline $\begin{array}{l}\text { Manufacturin } \\
\mathrm{g} \text { Industry } \\
\text { GDP }\end{array}$ & 6.98 & 5.45 & 5.61 & 5.04 & 5.65 & 5.78 \\
\hline $\begin{array}{l}\text { Manufacturi } \\
\text { ng Industry } \\
\text { Contribution }\end{array}$ & $\begin{array}{l}17.9 \\
9\end{array}$ & $\begin{array}{l}17.7 \\
4\end{array}$ & $\begin{array}{l}17.8 \\
9\end{array}$ & $\begin{array}{l}18.1 \\
8\end{array}$ & $\begin{array}{l}20.5 \\
1\end{array}$ & $\begin{array}{l}20.1 \\
6\end{array}$ \\
\hline
\end{tabular}

Source: The Catalog of Manufacturing Industry Productions Growth Index 2012-2017

Based on the above explanation and the Resource-Based View theory, the objective of this study is to see how the effect of the implementation of ERP system to firm performance either directly and indirectly through the organizational capabilities as intervening variable. Related to that, then the problem formulation that will be examined in this study are as follows: (1) Does the implementation of ERP systems affect the firm performance?; (2) Does the implementation of ERP systems affect the organizational capabilities?; (3) Do the organizational capabilities affect the firm performance?; (4) Does the implementation of the ERP system indirectly affect the firm performance through the organizational capabilities?

\section{LITERATURE REVIEW}

\section{A. Overview of Enterprise Resource Planning (ERP)}

Enterprise Resource Planning (ERP) system is the core software program used by companies to integrate and coordinate information in every business area. It helps organizations manage the entire enterprise business process, using shared databases and shared management reporting tools (11). ERP system combines business processes and IT technologies from implementing organizations to facilitate information flow through business functions (12). One of the very important parts of ERP is integration. Integration contributes to improve the communication and workflow.
ERP software supports efficient business process operations by integrating tasks related to sales, marketing, manufacturing, logistics, accounting, and staffing - across the business. In addition to this cross-functional integration, which is the core of ERP systems, companies connect their ERP systems, using a variety of methods, to coordinate business processes with their customers and suppliers (11). ERP enables an organization to maximize data sharing seamlessly across the organization, reduce costs, improve customer satisfaction and utilize e-business (13). ERP can help organizations integrate information flows, operations, and process all accessible resources (14) thus that companies which adapted ERP system have a greater performance than companies which did not adapted ERP system $(8,15)$.

\section{B. $\quad$ The Resource-Based View (RBV)}

Over the last fifteen years, two distinctive strands of strategy literature explaining sources of competitive advantage have developed. One builds predominantly on the theory of industrial organization, the other, currently the prominent theory, is a Resource-Based View (RBV) (16). $\mathrm{RBV}$ is a major theory in strategic management that argues that the competitive advantage of an organizational is determined by the key resources owned by the organization. Resources are referred to as all of the assets, capability, organizational processes, company attributes, information, knowledge, and others that are controlled by the company which therefore enable the company to understand and implement strategies that improve its efficiency and effectiveness (17). RBV tries to explain business performance in terms of company's specific skills and unique resources, namely valuable, rare, difficult to imitate, and non-substitutable (VRIN)(17,18). In summary, the Resource-Based View from corporate theory is very useful for defining resource conditions, including information technology and other organizational factors to be a source of competitive advantage. Information systems may enable companies to obtain competitive advantage when they are valuable for the company, heterogeneously distributed, leveraged, and costly to copy within industry. In addition, the concept of resource complementarity is useful to explain how information technology creates organizational capabilities, competitive advantage and eventually improved organizational performance. ERP systems that fulfill the VRIN conditions within the companies and create organizational capabilities allow the companies to have sustainable competitive advantage and to improve firm performance (19)

\section{Firm Performance}

One way to evaluate a firm performance is through the analysis of financial statements using traditional accounting measurements that are based on the relationships between items of financial statements (15). The firm performance in this study is seen from the financial performance that is related to the profitability of the company. Profitability is 
the company's ability to generate profits with the company's resources (20). In this study, the firm performance is reflected through ROA, ROE, and NPM.

\section{1) Return on Assets}

Return on Assets (ROA) is a measurement that is often used by researchers to measure financial performance $(1,10,15,21,22)$. This is because ROA combines both the profitability and the efficiency of a company that tends to be useful as an overall performance indicator (15) that indicates a company's ability to generate profits from the used assets (20).

\section{2) Return on Equity}

Return on Equity (ROE) ratio shows the extent to which company manage capital effectively, measuring the profitability of investments that have been made by the owners of their own capital or corporate shareholders (23).

\section{3) Net Profit Margin}

Net Profit Margin (NPM) measures the net income generated from each Rupiah sale. The greater this ratio, the better the company's ability to earn high profits (20). High NPM ratio indicates that the company is able to increase its business through the achievement of operating profit in that period (23).

\section{Organizational Capabilities}

Organizational capability is a firm's abilities to perform a set of tasks using company resources (24) to create competitive advantage by leveraging organizational resources such as information system to develop unique and change-oriented capabilities that enable them to meet customer needs and respond to challenges from competitors (25). Investment in IT enables company to make its processes more efficient, and it facilitates the company to achieve operational and financial outcomes by increasing information access, developing new products quickly and effectively, improving operations, and taking effective actions to alter the amounts and timing of cash flows. Organizational capabilities are recognized in the resourcebased view strategy literature as one of the primary source of competitive advantage (24). Also, the use of resourcebased models to examine the relationship between IT and firm performance in IS research is inconclusive when the research model does not include organizational capabilities. Hence, the indirect effect models that incorporate organizational capabilities as mediators between enterprise resources and firm performance may explain better the value of IT than the direct effect of RBV model without organizational capability (7). Organizational capabilities play an important role in influencing ERP implementation and performance. It indicates that the implementation of ERP has a significant effect on organizational capabilities and competitive advantage that will ultimately lead to performance (26). The same results also proves that there is an indirect relationship between ERP implementation and financial performance through mediation of organizational capabilities which seen from Operational, Marketing and Financial Capability (21).

\section{1) Operational Capability}

Operational capability is a basic capability that enables a company to achieve its production goals such as superior product quality, product and volume flexibility, fast delivery and cost reduction (27); (28). Operational capability can improve firm performance by developing existing products (product and process innovation) and operating costs (21). Operational capability in this study is measured through Operating Profit Margin (OPM) and Operating Income Return on Investment (OIROI). OPM shows how much profit that company generates after paying production costs, such as wages, raw materials, and so on. Meanwhile, OIROI shows how the performance of the company's core business hence the main revenue from the actual company can be evaluated.

\section{2) Marketing Capability}

Marketing capability is defined as an integrative process, whereby firms use both tangible and intangible resources to understand consumer needs (21). Marketing capability provides value-added knowledge to managers about how business processes transform marketing capability into business performance gains (29). In this research, marketing capability is measured from the sales growth of company (Sales Growth-SG). The company's sales growth is used as a market-based performance indicator because it assesses how well companies perform in the market and it relies on new product/service introductions and better customer targeting, and satisfies the customer needs (3).

\section{3) Financial Capability}

Financial capability referred to in this study is financial flexibility which measures how far companies utilize the unexpected opportunities or to deals with unexpected events depending on the company's financial policies and structure. Firms that are financially flexible have the ability to use financial resources to respond to the new information about the company and its environment (5). The financial capability in this study is measured through the Cash Debt Coverage (CDC) indicator. The CDC looks at the relationship between the operating cash flow of the company toward its total liabilities and implies the true ability of the business to repay its debts from its operations.

\section{E. Conceptual Framework and Hypotheses Formulation}

The framework in Figure 1 below illustrates the relationship between ERP system implementation, organizational capabilities, and firm performance that developed based on RBV theory and the evidence from existing empirical research results from previous study. 


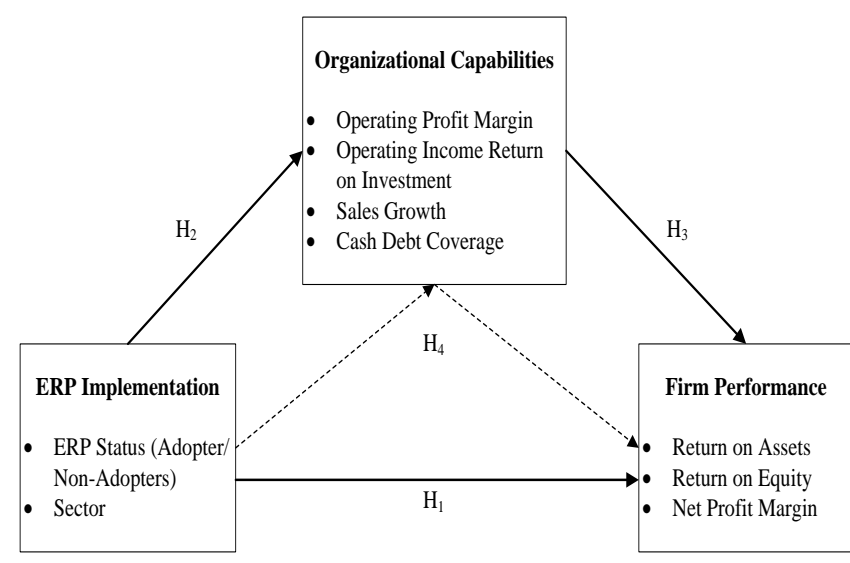

Figure 1 Conceptual Framework

Source: Developed by the author

Based on the conceptual framework in Figure 1, the hypotheses in this study can formulated as follows:

$\mathrm{H}_{1}$ : Implementation of ERP system has a significant effect on firm performance.

$\mathrm{H}_{2}$ : Implementation of ERP system has a significant effect on organizational capabilities.

$\mathrm{H}_{3}$ : Organizational capabilities have a significant effect on firm performance.

$\mathrm{H}_{4}$ : Implementation of ERP system has a significant indirect effect on firm performance through organizational capabilities as intervening variable.

\section{METHODOLOGY/MATERIALS}

\section{A. Exogenous Latent Variable}

The exogenous latent variable is the implementation of ERP system which is measured by ERP status and sector. ERP status is the status of the implementation of ERP system that is divided into ERP Adopters and Non-Adopters that are measured by dummy variables, in which 1 for Adopters and 0 for Non-Adopters. Meanwhile, sector is referring to the type of sectors in manufacturing companies, that is 1 for Basic Industry and Chemicals Sectors, 2 for Miscellaneous Industry Sector, and 3 for Consumer Goods Industry Sector.

\section{B. Endogenous Latent Variable}

The endogenous latent variable is the firm performance, which is measured by ROA, ROE, and NPM. ROA is calculated by dividing the net income of the company with total asset. Meanwhile, ROE is calculated by dividing the net income of the company with total equity and NPM is calculated by dividing the net income of the company with net sales.

\section{Intervening Variable}

Intervening variable is organizational capabilities that is seen from operation capability, marketing capability, and financial capability. Operation capability is measured through OPM by dividing the operating income to sales and OIROI by dividing the operating income to total assets. Meanwhile, the marketing capability is measured through SG by comparing the difference between the sales of the year $t$ period and the previous year $(\mathrm{t}-1)$ with the previous year's sales (t-1) and financial capability is measured through CDC by comparing net cash flow from operating activities to total liabilities.

\section{Population and Sample Sampling Method}

The population used in this study is a manufacturing companies listed on the Indonesia Stock Exchange (IDX) period 2013-2017. The sample was determined by purposive sampling method with the following criteria: (1) Manufacturing companies listed on the Indonesia Stock Exchange in 2013 - 2017; (2) Manufacturing companies that issue annual reports and financial statements that end on 31 December consistently during the study period 2013 - 2017; (3) Manufacturing companies that have implemented ERP system before 2013 (specific criteria for adopters); (4) Manufacturing companies that have a complete data related in this study during the period 2013 - 2017. Hence, 100 samples are obtained which consist of 50 from ERP Adopters companies and 50 NonERP Adopters companies.

\section{E. Data Types and Sources}

The data used in this study is secondary data in the form of quantitative and qualitative data obtained from the Indonesia Stock Exchange website (www.idx.co.id). The qualitative data required in this research is ERP implementation status and time of application of ERP system which are also obtained from company official website and search result through search engine of Google. The quantitative data is obtained from the annual financial report, which is calculated in order to obtain the value of

ROA, ROE, NPM, OPM, OIROI, SG, and CDC ratios.

\section{F. Data Analysis Technique}

This study uses some software to process data related variables contained in the research. First, Microsoft Excel is used to calculate and prepare data related variables and indicators that have been searched through various sources such as financial reports and annual reports. Second, data were analyzed using Partial Least Square (PLS) based Structural Equation Modeling (PLS) method (PLS-SEM) using SmartPLS3 (Professional Version) software to test the model fit and hypothesis testing in this study. PLS-SEM was used because this method has the advantage of allowing the data that is not normally distributed in structural equation modeling because the application is done by non-parametric methods. PLS-SEM does not use a global model fit criteria such as the covariance-based SEM. The criteria used in the SEM PLS include: a) assessment of the outer model or also called a measurement model, which is connecting all manifest variables or indicators with latent variables and $b$ ) assessment of the inner model or structural model, which is where all the latent variables are connected with each other based on the theory.

\section{RESULTS AND FINDINGS}

\section{A. Measurement Model (Outer Model)}

The measurement model is generally used for 
Confirmatory Factor Analysis (CFA). The measurement model in this study uses a reflective measurement model. Reflective measurement models should be assessed with reliability and validity to achieve their consistency. The reliability measures how large or how reliable the measurement model is in measuring the intended latent construction, while the validity is a measure of the accuracy of the instruments used in the study. The reliability tested in the PLS-SEM model in this study consists of two tests, namely Indicator Reliability and Internal Consistency Reliability.

\section{B. Reliability}

Indicator Reliability The result of reliability test in Table 2 shows that the eight of nine variants of indicators that can be explained by the latent variables because the absolute correlation between latent variables and indicators are greater than 0.70 while one other indicator has a value smaller than 0.70 . On the other hand, the other one indicator that is the SG indicator only has an outer loading value of 0.173 where the value is smaller than 0.70 thus it can be said that the SG (Sales Growth) indicator is not an indicator of the marketing capability variable of the company.

Table 2. Indicator Reliability Testing Result

\begin{tabular}{|l|l|l|l|}
\hline & ERP & $\begin{array}{l}\text { Firm } \\
\text { Performance }\end{array}$ & $\begin{array}{l}\text { Organizational } \\
\text { Capabilities }\end{array}$ \\
\hline CDC & ---- & ----- & 0.778 \\
\hline $\begin{array}{l}\text { ERP } \\
\text { STATUS }\end{array}$ & 0.729 & ---- & ---- \\
\hline NPM & --- & 0.905 & ---- \\
\hline OIROI & ---- & ---- & 0.932 \\
\hline OPM & ---- & ---- & 0.898 \\
\hline ROA & ---- & 0.952 & ---- \\
\hline ROE & ---- & 0.821 & ---- \\
\hline SECTOR & 0.797 & ----- & ---- \\
\hline SG & ---- & ---- & 0.173 \\
\hline
\end{tabular}

Source: Secondary data processed, 2018

Internal Consistency Reliability The result of internal consistency reliability test in Table 3 shows that the three variables in this study, namely the implementation of ERP systems, firm performance and organizational capabilities have a greater value than 0.70 . In other words, the internal consistency reliability of the three latent variables is above the standard value. Thus, it can be said that the three variables have an ideal reliability.

Table 3. Internal Consistency Reliability Testing Result

\begin{tabular}{|c|c|}
\hline & $\begin{array}{c}\text { Composite } \\
\text { Reliability }\end{array}$ \\
\hline ERP & 0.737 \\
\hline Firm Performance & 0.923 \\
\hline $\begin{array}{c}\text { Organizational } \\
\text { Capabilities }\end{array}$ & 0.820 \\
\hline
\end{tabular}

Source: Secondary data processed, 2018

\section{Validity}

Convergent Validity The convergent validity test result in Table 4 shows that the three variables in this study, namely the implementation of ERP systems, firm performance, and organizational capabilities have a greater AVE's value than 0.50 . In other words, the test results of convergence validity indicate that the model in this study is adequate. Thus, it can be said that the three variables in this research model can explain each indicator or can represent each indicator.

Discriminant Validity The measurement of discriminant validity in this study used two criteria, namely FornellLarcker and Cross-loadings criteria. The Fornell-Larcker criterion assesses discriminant validity at the construct level (latent variable), where the AVE square's root must be higher than the correlation with other latent variables. While 'cross-loading' assesses discriminant validity at the indicator level, where 'loading' for each indicator is expected to be higher than its 'cross-loading'.

The discriminant validity test result in Table 5 at the level of constructs (latent variables) using Fornell-Larcker Criterion shows that each individual construct (ERP, firm performance, and organizational capabilities) has a larger AVE root square than the correlation with the other constructs. Hence, it can be seen that each latent variable shares more variants with each indicator block than with other latent variables that representing a different indicator block. It also shows that discriminant validity is ensured for this study, because AVE's square root for ERP, firm performance, and organizational capabilities are higher than correlations of the corresponding latent variables. Moreover the discriminant validity test result at the indicator level by looking at the value of 'cross-loading' shows that all 'loading' value of each indicator in this study is higher than its each 'cross-loading' thus all the indicators in this study are valid.

Table 4. Convergent Validity Testing Result

\begin{tabular}{|c|c|}
\hline & $\begin{array}{c}\text { Average Variance Extracted } \\
\text { (AVE) }\end{array}$ \\
\hline ERP & 0.584 \\
\hline Firm Performance & 0.800 \\
\hline $\begin{array}{c}\text { Organizational } \\
\text { Capabilities }\end{array}$ & 0.577 \\
\hline
\end{tabular}

Source: Secondary data processed, 2018

Table 5. Discriminant Validity Testing Result Fornell-Larcker Criterion

\begin{tabular}{|l|c|c|c|}
\hline & ERP & $\begin{array}{c}\text { Firm } \\
\text { Performance }\end{array}$ & $\begin{array}{c}\text { Organizational } \\
\text { Capabilities }\end{array}$ \\
\hline ERP & 0.764 & ----- & ----- \\
\hline $\begin{array}{l}\text { Firm } \\
\text { Performance }\end{array}$ & 0.300 & 0.894 & ----- \\
\hline $\begin{array}{l}\text { Organizational } \\
\text { Capabilities }\end{array}$ & 0.292 & 0.877 & 0.760 \\
\hline
\end{tabular}

\begin{tabular}{|l|c|c|c|}
\hline \multicolumn{1}{|c|}{} & Cross Loadings & \\
& ERP & $\begin{array}{c}\text { Firm } \\
\text { Performance }\end{array}$ & $\begin{array}{c}\text { Organizational } \\
\text { Capabilities }\end{array}$ \\
\hline CDC & 0.170 & 0.598 & 0.778 \\
\hline ERP STATUS & 0.729 & 0.214 & 0.209 \\
\hline NPM & 0.195 & 0.905 & 0.803 \\
\hline OIROI & 0.355 & 0.868 & 0.932 \\
\hline OPM & 0.207 & 0.799 & 0.898 \\
\hline
\end{tabular}


International Conference on Recents Advancements in Engineering and Technology (ICRAET-18) |15th and 16th March 2019|Siddhartha Institute of Technology \& Sciences, Telangana, India.

\begin{tabular}{|l|l|l|l|}
\hline ROA & 0.321 & 0.952 & 0.895 \\
\hline ROE & 0.293 & 0.821 & 0.625 \\
\hline SECTOR & 0.797 & 0.243 & 0.236 \\
\hline SG & 0.075 & 0.115 & 0.173 \\
\hline
\end{tabular}

Source: Secondary data processed, 2018

\section{Structural Model Measurement (Inner Model)}

Coefficient of Determination (R-Square) The coefficient of determination or $\mathrm{R}^{2}$ is the overall measure for the structural model. The main criterion for inner model assessment is the coefficient of determination $\left(\mathrm{R}^{2}\right)$, which represents the amount of variance explained by each endogenous latent variable. The value of $\mathrm{R}^{2}$ on firm performance variable is 0.772 . This means that the combined effect of ERP system implementation variables along with the two indicators, namely ERP STATUS and SECTOR with the organizational capabilities variable along with its four indicators, namely OPM, OIROI, SG, and CDC jointly explain $77.2 \%$ of the variance. Whereas, the value of $\mathrm{R} 2$ on variable is 0.085 ,it means that the combined effect of ERP system implementation variables along with the two indicators, namely ERP STATUS and SECTOR explains $8.5 \%$ of the variance.

Table 6. Coefficient of Determination Testing Result

\begin{tabular}{|l|l|l|}
\hline & $\begin{array}{l}\mathrm{R} \\
\text { Square }\end{array}$ & $\begin{array}{l}\text { R Adjusted Square } \\
\text { Firm Performance }\end{array}$ \\
\hline $\begin{array}{l}\text { Organizational } \\
\text { Capabilities }\end{array}$ & 0.772 & 0.771 \\
\hline
\end{tabular}

Source: Secondary data processed, 2018

Path Coefficient Path coefficient measures the relationship between constructs in the PLS-SEM research model. The standard path coefficients provide the evidence of inner model quality. Based on the test results it is known that the effect of ERP system implementation on the firm performance has a weak effect because the value is close to 0 , but the resulting effect is a positive effect. The effect of ERP system implementation on organizational capabilities has a positive effect. The effect of the organizational capabilities to the firm performance has a very strong positive effect because its value is close to +1 .

Table 7. Path Coefficient Testing Result

\begin{tabular}{|l|l|l|}
\hline & $\begin{array}{l}\text { Firm } \\
\text { Performance }\end{array}$ & $\begin{array}{l}\text { Organizational } \\
\text { Capabilities }\end{array}$ \\
\hline ERP & 0.048 & 0.292 \\
\hline $\begin{array}{l}\text { Organizational } \\
\text { Capabilities }\end{array}$ & 0.863 & ------ \\
\hline
\end{tabular}

Source: Secondary data processed, 2018

Effect Size $\left(f^{2}\right)$ The effect size test was performed to evaluate whether the removed construction has substantive impact on the endogenous construction. In Table 8 it shows that the ERP has a small effect size on firm performance and organizational capabilities. This means that when the ERP's exogenous construction was removed from the model, the substantive impacts on the endogenous construction are small, while the organizational capabilities variable has big effect size to firm performance.
Table 8. Effect Size (f2) Testing Result

\begin{tabular}{|l|l|l|}
\hline & $\begin{array}{l}\text { Firm } \\
\text { Performance }\end{array}$ & $\begin{array}{l}\text { Organizational } \\
\text { Capabilities }\end{array}$ \\
\hline ERP & 0.009 & 0.093 \\
\hline $\begin{array}{l}\text { Organizational } \\
\text { Capabilities }\end{array}$ & 2.983 & ------ \\
\hline
\end{tabular}

Source: Secondary data processed, 2018

Predictive Relevance $\left(\mathrm{Q}^{2}\right)$ Predictive relevance testing is a measure of conformity model used to determine whether the endogenous construction indicator (reflective measurement model) can be accurately predicted. The test results of the model fit measurements seen from the predictive relevance as measured through the Stone-Gleisser $\mathrm{Q}^{2}$ value through cross-validated redundancy construct. Based on the test results, it can be seen that the value of $\mathrm{Q}^{2}$ on the firm performance variable and organizational capabilities variable in this research model in a row is 0.577 and 0.045 where the value of $\mathrm{Q}^{2}$ is greater than 0 . This indicates that the observed values are reconstructed properly. Thus, the research model in this thesis has predictive relevance.

Table 9. Predictive Relevance (Q2) Testing Result

\begin{tabular}{|l|l|l|l|}
\hline & SSO & SSE & $\begin{array}{l}Q^{2} \quad(=1- \\
\text { SSE/SSO) }\end{array}$ \\
\hline ERP & $1,000.000$ & $1,000.000$ & ---- \\
\hline $\begin{array}{l}\text { Firm } \\
\text { Performance }\end{array}$ & $1,500.000$ & 634.483 & 0.577 \\
\hline $\begin{array}{l}\text { Organizational } \\
\text { Capabilities }\end{array}$ & $2,000.000$ & $1,910.032$ & 0.045 \\
\hline
\end{tabular}

Source: Secondary data processed, 2018

Based on the hypotheses testing result in Table 10, the results of hypothesis testing $1\left(\mathrm{H}_{1}\right)$ shows that the implementation of ERP system has a significant positive effect on firm performance. It can be seen from the path coefficient of ERP to firm performance which has t-statistic value of 2.427 which is greater than 1.96 and the significance value of P-Values is 0.015 where the value is less than 0.05 . This shows that $\mathrm{H}_{1}$ is accepted which means that with the implementation of ERP system to the company, it will improve the firm performance. This study shows that the companies in the research sample that have implemented ERP systems already felt the positive impact of the implementation of the integrated system in the form of improving firm performance as measured by ROA, ROE, and NPM. This proves that the use of ERP system in a company has proved to improve both profitability and efficiency of company and is able to generate profits from the assets, resources used and investments made in implementing ERP. The use of effective information technology as well as with the ability of better information systems like ERP system can improve efficiency by facilitating business processes and all activities that occur in the company and can reduce the operating costs. Moreover, ERP provides a rich source of information that enables companies to develop business strategies that generate 
growth and innovation and provide access to customer and market data which lets companies to know and evaluate the external growth opportunities.

Table 10. Hypotheses Testing Result

\begin{tabular}{|l|l|l|l|l|l|}
\hline & $\begin{array}{l}\text { Origin } \\
\text { al } \\
\text { Sample } \\
(\mathrm{O})\end{array}$ & $\begin{array}{l}\text { Sampl } \\
\mathrm{e} \\
\text { Mean } \\
(\mathrm{M})\end{array}$ & $\begin{array}{l}\text { Standard } \\
\text { Deviatio } \\
\mathrm{n} \\
(\text { STDEV } \\
\text { (ST Statistics }\end{array}$ & $\begin{array}{l}\text { (|O/STDEV } \\
\text { () }\end{array}$ & $\begin{array}{l}\text { Value } \\
\mathrm{s}\end{array}$ \\
\hline $\begin{array}{l}\text { ERP -> Firm } \\
\text { Performance }\end{array}$ & 0.048 & 0.044 & 0.020 & 2.427 & 0.015 \\
\hline $\begin{array}{l}\text { ERP -> } \\
\text { Organization } \\
\text { al } \\
\text { Capabilities }\end{array}$ & 0.292 & 0.299 & 0.038 & 7.776 & 0.000 \\
\hline $\begin{array}{l}\text { Organization } \\
\text { al } \\
\text { Capabilities - } \\
> \\
\text { Performance }\end{array}$ & 0.863 & 0.865 & 0.015 & 55.848 & 0.000 \\
\hline $\begin{array}{l}\text { ERP Firm }> \\
\text { Organization } \\
\text { al } \\
\text { Capabilities - } \\
>\text { Performance }\end{array}$ & 0.252 & 0.258 & 0.032 & 7.761 & 0.000 \\
\hline
\end{tabular}

Source: Secondary data processed, 2018

The result of hypothesis testing $2\left(\mathrm{H}_{2}\right)$ shows that the implementation of ERP system has significant positive effect on organizational capabilities. It can be seen from the path coefficient of ERP to organizational capabilities which has $\mathrm{t}$-statistic value of 7.776 which is greater than 1.96 and the significance value of P-Values is 0.000 where the value is less than 0.05. This shows that $\mathrm{H}_{2}$ is accepted which means that with the implementation of ERP system to the company, it will improve the organizational capabilities. Implementing an ERP system in a company can improve the company's operational capability in terms of its ability to improve productivity, innovation and production goals, such as improving product quality and reducing operating costs and also can simplify as well as accelerate the production process. ERP systems transforms the existing system in a company into an integrated system which therefore allows companies to make business processes more efficient and enable companies to achieve maximum operational and financial results by improving access to information, develop new products quickly and effectively, improve operations, and take effective actions to increase the amount of cash flow. Also, it can facilitate the company in sharing the information between divisions that obtained rich information which can be viewed in real-time thus that the company can know the state of the condition of the company and enable company to make strategic moves regarding on what company needs to do next. In terms of operations, the company can find out the information generated from the ERP system in the form of data about the production that has been done. Thus, the company can improve the strategy in improving the productivity and the quality of its products and make the appropriate strategies for each product depending on the sales performance. Implementing an ERP system that affects the operating capability associated with sales will have an impact on the company's financial capability. With the increase in productivity and sales, the company's cash flow from operating activities will be higher. This will have an impact on improving the company's ability to pay the obligations of its core business and make the company stronger to face any unexpected changes. Thus, it can be concluded that the implementation of integrated systems in companies such as the ERP system connects all divisions within the company into one system which allows sharing of information easily. In fact, not just the information, but ERP system provides the rich information for the company. If the company can utilize the rich information properly, it will have an impact on improving the organizational capabilities through the operating capabilities and financial capabilities.

The results of hypothesis testing $3\left(\mathrm{H}_{3}\right)$ shows that the organizational capabilities have a significant positive effect on firm performance. It can be seen from the path coefficient of organizational capabilities to firm performance which has t-statistic value of 55.848 which is greater than 1.96 and the significance value of $\mathrm{P}-$ Values is 0.015 where the value is less than 0.000 . This shows that hypothesis $3\left(\mathrm{H}_{3}\right)$ is accepted which means that the higher the organizational capabilities, the higher the firm performance. The organizational capabilities describe the company's ability to take advantage of all its competencies and resources to cope with all the changes that are taking place due to the rapidly changing environment and business development. With the development of the organizational capabilities by utilizing organizational resources such as information systems, companies can create competitive advantage that will improve firm performance. The increase in capabilities related to these operations is evident from the OPM ratio that demonstrates the organizational capabilities to increase operating revenues and its efficiency in controlling costs associated with business operations. This can affect the increase in the overall net profit of the company hence it shows a good performance improvement. In addition, the increased capability related to operating activities is also inseparable from the ratio of OIROI which shows the organizational capabilities to increase revenue from its core business as well as its ability to obtain return on assets used. This results in an increase in operating profit that will ultimately provide an improvement in the firm performance. In addition to operating capabilities, good financial capability is important for companies to enable them to use their financial resources to respond to the new information about the company itself and its environment. In this case, the financial statements present useful information to evaluate the company's financial capability. Thus, the greater the net amount of future cash flows generated from operations in a company, the firm will be stronger in addressing the unexpected changes in operating conditions. In addition, the organizational capabilities to increasing the net cash flows generated from operating activities in a company indicate its ability to repay its debts from operating activities. 
Therefore, an increase in financial capability indicates that the company is becoming stronger in the face of any changes and can become a buffer if the company is down. Therefore, it can be said that companies with good/high financial capability have good firm performance as well.

The results of hypothesis testing $4\left(\mathrm{H}_{4}\right)$ shows that the implementation of ERP system has a significant positive effect on firm performance indirectly through the organizational capabilities as a mediator. It can be seen from the path coefficient of ERP towards the organizational capabilities that subsequently led to the firm performance which has t-statistic value of 7.761 which is greater than 1.96 and the significance value of P-Values is 0.000 where the value is less than 0.000 . This shows that hypothesis 4 $\left(\mathrm{H}_{4}\right)$ is accepted which means that with the implementation of the ERP system in the company, it will increase the organizational capabilities which will ultimately improve the firm performance. The use of ERP system in a company has proven to improve the organizational capabilities which ultimately able to improve the profitability and the efficiency of company. This shows that with the collaboration between the implementation of the ERP system which indeed makes the information system to be integrated and the organizational capabilities which can maximize the utilization of resources in the company has managed to generate profits from assets and resources used. It is also proven to improve the profitability of the investments made by the company. In addition, it is shown that the company can create competitive advantage by utilizing organizational resources such as information systems thus the company's business processes will run smoothly which will eventually able to increase its business through the achievement of net profit in each period. With the implementation of ERP system, the company can improve its ability in overcoming all rapidly changing business development by utilizing all competence and its resources. The competences and resources that are maximally utilized can create a competitive advantage that allows the company to improve the firm performance.

The results of this study are consistent with research conducted by (7) which states that the use of resource-based models to investigate the relationship between IT and firm performance in IS research has been inconclusive when the research model does not include organizational capability. Compared with the direct effect of the ERP system implementation on the firm performance that have a $t$ statistical value of 2.427 with a significance value of $\mathrm{P}$ value that is 0.015 , the indirect effect has a t-statistical value of 7.761 with a significance value of P-value of 0.000 . A higher t-statistic value and smaller significance value of $\mathrm{P}$ value indicates that the effect of ERP system implementation on firm performance is stronger with the organizational capabilities as intervening variable. It means that the mediation effect of the organizational capabilities is Complementary Partial Mediation. This is because the effect of independent variables of the ERP system implementation has a significant direct effect on the dependent variable of firm performance and also has a significant indirect effect mediated by the organizational capabilities with an equally positive direction. Thus, it can be said that the organizational capabilities play an important role as a mediator in the relationship between the implementation of the ERP system to the firm performance.

By utilizing the rich information generated from the ERP system, the company can achieve production targets, such as increasing productivity, improving product quality, knowing product sales data (such as which products are sold and unsold) hence that companies can make the right strategy for each product and it will ultimately increase the cash flow generated from the company's operating activities. The cash flows from high operating activities indicate that the company is able to pay the liabilities of the company's core business. It also indicates that the future cash flows of the company is ensured thus the company has the strength in the face of unexpected changes in operating conditions. Thus, companies that have implemented ERP systems will have better capabilities and ultimately will improve firm performance. This implies that the companies that use their capabilities to utilize their resources have felt the true impact and the real value of technology investments. That is because the real impact can be traced compared to just looking directly at the firm performance. In addition, the rich information from the ERP system becomes useless if the company is unable utilize that information.

\section{CONCLUSION}

The implementation of ERP system makes companies become more efficient in their business processes thus it can increase the profitability of the investments that have been made. Also, it can generate profits from assets and resources used so as to encourage the improvement of firm performance. Implementing an ERP system makes the system in all divisions that exist in the company to be integrated thus the organizational capabilities in utilizing all available resources will have an impact on improving the operational and financial capabilities. This shows that the companies that pay attention on their organizational capabilities can improve the performance of the company. The organizational capabilities in maximizing the use of its resources have resulted in the company generating profits from the assets and resources used and also proven to increase the profitability of each sale made thus it will improve the firm performance. In short, this study proves that the implementation of ERP system makes the information system becomes integrated thus it enables the company to be more efficient which therefore will affect the company's capability in maximizing the utilization of company resources that ultimately can improve the performance of the company. Finally, this study suggests that if the companies want to successfully implement the ERP system, they should pay attention to their organizational capabilities thus the impact of the ERP system on the firm performance will be more visible. The empirical literature that has been reviewed shown that when the companies develop the collaborative relationships with organizational capabilities to implement ERP systems and know exactly what they are doing to implement them successfully, the companies can enhance their firm performance. 


\section{REFERENCES}

1. Ali I. The Impact of ERP Implementation on the Financial Performance of the Firm: An Empirical Study. Tilburg: CentER, Center for Economic Research; 2016.

2. Le MD, Han KS. Understanding the Impact of ERP System Implementation on Firm Performance - Focused on Vietnamese SMEs. International Journal of Software Engineering and Its Applications. 2016;10(9):87-104.

3. Ravichandran T, Lertwongsatien C. Effect of Information Systems Resources and Capabilities on Firm Performance: A Resource-Based Perspective. Journal of Management Information Systems. 2005;21(4):237-76.

4. Ahlawat J, Punam. ERP Systems and Business Performance. International Economics \& Finance Journal. 2011;6(2):273-86.

5. HassabElnaby HR, Hwang W, Vonderembse MA. The Impact of ERP Implementation on Organizational Capabilities and Firm Performance. Benchmarking: An International Journal. 2012;19(4/5):618-33.

6. Hastuti D, Dalle J, Khatimi H. An Empirical Evaluation of ERP Values Using RBV Approach in Indonesia. In: International Conference on Science in Information Technology (ICSITech). 2016. p. 26-9.

7. Liang T-P, You J-J, Liu C-C. A Resource-Based Perspective on Information Technology and Firm Performance: A Meta Analysis. Industrial Management \& Data Systems. 2010;110(8):1138-58.

8. Voulgaris F, Lemonakis C, Papoutsakis M. The Impact of ERP Systems on Firm Performance: The Case of Greek Enterprises. Global Business and Economics Review. 2015;17(1):112-29.

9. Ngai EWT, Law CCH, Wat FKT. Examining the Critical Success Factors in the Adoption of Enterprise Resource Planning. Computers in Industry. 2008;59:548-64.

10. Parto A, Sofian S, Saat MM. The Impact of Enterprise Resource Planning on Financial Performance in a Developing Country. International Review of Management and Business Research. 2016;5(1):176-87.

11. Monk E, Wagner B. Concepts in Enterprise Resource Planning. Fourth Edi. Boston: Course Technology, Cengage Learning; 2013. 1-274 p.

12. Velcu O. Exploring the Effects of ERP Systems on Organizational Performance Evidence from Finnish Companies. Industrial Management \& Data Systems. 2007;107(9):1316-34.

13. Forcht KA, Kieschnick E, Aldridge A, Shorter JD. Implementing Enterprise Resource Planning (ERP) for Strategic Competitive Advantage. Issues in Information Systems. 2007; VIII(2):425-9.

14. Alkhaffaf $M$, Aldalahmeh M. Enterprise Resources Planning Effectiveness and Organizational Performance : The case of "Jordanian Hashemite fund for human development ." Business and Economic Research. 2016;6(1):148-61.

15. Hunton JE, Lippincott B, Reck JL. Enterprise Resource Planning Systems: Comparing Firm Performance of Adopters and Nonadopters. International Journal of Accounting Information Systems. 2003;4:165-84.

16. Tichá I. Organizational Capabilities as a Source of Competitive Advantage: A Conceptual Framework. AGRIC ECON - CZECH. 2010;56(4):159-62.

17. Barney J. Firm Resources and Sustained Competitive Advantage. Journal of Management. 1991;17(1):99-120.

18. Wade M, Hulland J. Review: The Resource-Based View and Information Systems Research: Review, Extension, and Suggestions for Future Research. MIS Quarterly. 2004;28(1): 107-42.

19. Hwang W. The Drivers of ERP Implementation and Its Impact on Organizational Capabilities and Performance and Customer Value. 2011.
20. Murniati S. Effect of Capital Structure, Company Size and Profitability on the Stock Price of Food and Beverage Companies Listed on the Indonesia Stock Exchange. Information Management and Business Review. 2016;8(1):23-9.

21. Kurniawati M, Gunarta IK, Baihaqi I. Dampak Implementasi Enterprise Resource Planning (ERP) pada Kinerja Keuangan: Pendekatan Resources Based View. In: Prosiding Seminar Nasional Manajemen Teknologi XXIII. Surabaya; 2015. p. 1-9.

22. Xia XIE, Dai JB. Impact of ERP Adoption on the Profitability of Chinese Listed Companies in the Logistics Industry. International Journal of Management Science and Engineering Research. 2016;3(1):35-40.

23. Heikal M, Khaddafi M, Ummah A. Influence Analysis of Return on Assets (ROA), Return on Equity (ROE), Net Profit Margin (NPM), Debt To Equity Ratio (DER), and Current Ratio (CR), Against Corporate Profit Growth In Automotive In Indonesia Stock Exchange. International Journal of Academic Research in Business and Social Sciences. 2014;4(12):101-14.

24. Shang S, Seddon PB. Assessing and Managing the Benefits of Enterprise Systems: The Business Manager's Perspective. Information Systems Journal. 2002;12:27199.

25. Teece DJ, Pisano G, Shuen A. Dynamic Capabilities and Strategic Management. Strategic Management Journal. 1997;18(7):509-33.

26. Le TMD, Han KS. Factors Affecting Successful Implementation of ERP Systems Towards Organizational Performance - Focused on SMEs in Vietnam. European Journal of Business and Social Sciences. 2015;4(9):7292.

27. Terjesen S, Patel PC, Covin JG. Alliance Diversity, Environmental Context and the Value of Manufacturing Capabilities among New High Technology Ventures. Journal of Operations Management [Internet]. 2011;29(1-2):105-15. Available from: http://dx.doi.org/10.1016/j.jom.2010.07.004

28. Kamboj S, Goyal P, Rahman Z. A Resource-Based View on Marketing Capability, Operations Capability and Financial Performance: An Empirical Examination of Mediating Role. Procedia - Social and Behavioral Sciences [Internet]. 2015;189:406-15. Available from: http://dx.doi.org/10.1016/j.sbspro.2015.03.201

29. Brahmane J. An Empirical Study on Sales Capability and Marketing Implementation Capability of SMEs in India and Their Impact on Market Share. IOSR Journal of Business and Management (IOSR-JBM). 2014;16(11):716.

\section{AUTHORS PROFILE}

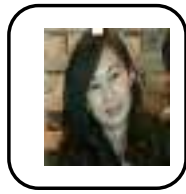

Euphrasia Susy Suhendra. has a rich experience of 27 years in academics and industry. She is a professor of Management in Gunadarma University, Indonesia. Currently, she is serving as a head of Post Graduate Management Program, and also as a lecturer in Strategic IT Management. She got some research grant from Indonesia Higher Education Directorate on research field. She is doing research collaboration with researchers in other fields such as Information Communication Technology, she is in charge in risk management of Indonesia Insurance Association. She is an instructor of risk management and insurance management training programs. She has many publications in the domain of Management Strategic in the International Journal/ Book Chapters/ National. She has successfully organized International Conferences and National Seminars in the last few years, and he has attended several corporate events and presented her research at various conferences. Her area of Interest is Strategic Management, IT Management, Financial Management. 
International Conference on Recents Advancements in Engineering and Technology (ICRAET-18) |15th and 16th March 2019|Siddhartha Institute of Technology \& Sciences, Telangana, India.

Mitha Filandari is an economics graduate majoring in accounting and a master graduate in management information system with the concentration of accounting information system at Gunadarma University. Mitha Filandari's work has been published in Economy and Sociology Journal, National Institute for Economic Research, Moldova, which examined and discussed the influence of earning management to firm value in Indonesia manufacturing companies.

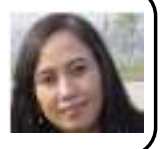

Emmy Indrayani is a lecturer and researcher in Gunadarma University Jakarta, Indonesia. Her teaching and research subjects are Accounting, Accounting Information System and Marketing. She earned her doctorate from Gunadarma University in the areas of marketing, especially consumer behavior. She got some research grant from Indonesia Higher Education Directorate on the same research field. She is doing research collaboration with researchers in other fields such as ICT and Civil Engineering, to solve complex social problem. She also did research collaboration with BKCU (Indonesia Credit Union Coordinating Board) on Credit Union strategic and member's welfare. She had been an instructor of government auditor training program. She is a research supervisor for Graduate Program, Magister Management Program, Undergraduate Program, and Ph.D thesis. She is also a Ph.D thesis examiner in Gunadarma University and also other institution as external examiner (i.e Anna University, Chennai, India). She is currently served as a Vice Dean on Academic Issues of Economics Faculty Gunadarma University.

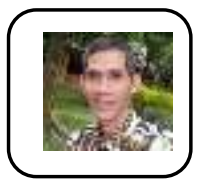

Maulana Ali is a lecturer and researcher in Tamansiswa Palembang University, Indonesia. His teaching and research subjects are Management Methodology and Human Resource Management. H earned his doctorate from Gunadarma University, in 2012, in the areas of Human Resources Management. He has several publications in the domain of Management Human Resource in the international journal/National. He also Successfully organized International Conference and National Seminars in the last few years. He has invited in several international Conference as a keynote speaker. He is doing research collaboration with researcher in other fields such as Government and Education $\mathrm{He}$ is a research supervisor for Graduate Program, Magister Government Science Program, Undergraduate Program, and Ph.D thesis. He is currently served as a Head of Research and Development of Tamansiswa Palembang University. 